\title{
1. Introduction: immigration in harder times
}

\author{
John Higley, John Nieuwenhuysen and \\ Stine Neerup
}

In the best of economic times, large-scale immigration is a complex and contested undertaking. It is conducted with an eye to business firms needing additional workers, trade unions seeking job and wage protection, human rights groups agitating against discrimination, immigrant communities wanting more ethnic brethren, citizen groups perceiving border protection as too harsh or lenient, population growth's environmental and infrastructural effects and, of course, opposition parties trying to capitalize on blunders and controversies.

Between the early 1990s and 2008, immigration to Australia and the US took place in the context of steady, at times spectacular, economic expansion conducive to nearly full employment and increasing prosperity. Australia's per capita gross domestic product (GDP) rose (in US dollars and 2009 prices) from about US\$31000 in 1994 to US\$37000 in 2008; US per capita GDP exploded from US\$33500 in 1999 to US\$46500 ten years later. Labour market demand for skilled and unskilled immigrants was strong; immigrant remittances to home countries increased markedly; immigrants moved without great difficulty to communities and regions with little previous experience of them. Swelling inflows of people put strong pressure on schools, health care, housing and other services, but economic expansion and robust tax revenue kept the pressures manageable. Despite controversial incidents involving refugees and asylum seekers, Australia's immigration policies enjoyed broad bipartisan political and public support. US immigration policies underwent no major changes, though clashing opinions about how to deal with millions of unauthorized arrivals created political acrimony.

Our earlier volume, Nations of Immigrants: Australia and the United States Compared (Higley, Nieuwenhuysen and Neerup, 2009), took stock of immigration to Australia and the US between the early 1990s and mid2008. It reviewed both countries' massive immigration intakes during 
those years, contrasting Australia's emphasis on skills-based immigration with the US's emphasis on family reunion, as well as Australia's generally effective border protection measures and the quite ineffective measures in the US. Labour market absorptions and settlement patterns of newly arrived immigrants were compared; the increasing frequency with which temporary visas, including overseas student visas, were being converted onshore into permanent residence status were highlighted; and the effects of large-scale immigration on social cohesion in both countries were determined. Overall, Nations of Immigrants concluded that in thriving economic conditions large-scale immigration was handled without inordinate difficulties in both countries, though with considerably greater policy coherence in Australia.

This second volume examines immigration to Australia and the US during the harder economic times that have followed the paralysis of financial firms and markets in New York and London during autumn 2008, which quickly affected Australia and most other Organisation for Economic Co-operation and Development (OECD) countries. During 2009 GDP in the US contracted by more than 3 per cent; Australia's GDP growth shrank from a robust average of 3.5 per cent per annum between 1994 and 2008 (a full percentage point above the OECD average for those years) to less than 1 per cent. In the 30 months between early 2008 and mid-2010, more than half of all US workers experienced a period of unemployment, a cut in pay or hours of work, or part-time employment. By mid-2010 some 15 million workers in the US were unemployed, typically for at least six months: there were five unemployed applicants for each job opening; a quarter of all unemployed persons aged 18 to 29 had returned to live with their parents; shrunken stock and housing market prices had destroyed roughly a fifth of the average household's wealth; two-thirds of all state governments were facing unsustainable budget deficits; some 240000 public sector employees had been laid off; and total US federal government indebtedness approached US\$14 trillion, nearly equal to the size of US GDP (Pew Research Center 2010).

Australia, by contrast, emerged fairly rapidly from the economic crisis that began in 2008, with its mid-2010 unemployment rate half the official US rate, banks and financial firms intact, and coal and iron exports, principally to China, continuing to boom. Yet Australians could not escape a sense that harder economic times had arrived. In Australia's most important export markets, China's prodigious economic growth was clearly slowing; Japan wallowed in deflation and enormous government debt; the eurozone was trying to cope with a sovereign debt crisis; and the US economy was anaemic at best. Surveying the economic outlook early in 2010, the World Bank observed: 
$[T]$ he depth of the recession has left the global economy seriously wounded. Even as profitability returns to many of the firms that were at the heart of the crisis, industrial production and trade levels have yet to regain their pre-crisis levels, and unemployment has reached double digits in many countries and continues to rise ... [U]nemployment and significant spare capacity are likely to continue to characterise the economic landscape for years to come. (World Bank 2010, p. xviii)

There were, in sum, many indications that a prosperous era had ended and a grimmer one had begun (Krugman 2009).

This volume ponders how these harder times are altering the nexus of domestic labour markets and immigration, how public fears spurred by harder times are affecting border protection and support for immigration, whether serious abrasions between foreign- and native-born populations are being kindled, and the extent to which the politics of immigration are being transformed. Structural needs for immigrant labour in health care, restaurants, tourism, agricultural and other economic sectors, together with harsher economic circumstances in most sending countries, almost certainly ensure the continuation of large-scale immigration to Australia and the US. But in harder times, especially in the US, sustaining this immigration while managing immigrants' economic and social integration are daunting tasks. In what ways and how well will Australia and the US meet them?

\section{CONTRASTING SOCIETAL AND POLITICAL CONTEXTS}

Australia and the US differ in many respects salient to immigration. Although both countries originated as clutches of British colonies-13 American and six Australian colonies-Australia's history of European settlement, dating effectively from 1800, is only half as long as the US's, which began in the early 1600s. Predominantly British immigrants settled both countries, but large-scale immigration of other Europeans to the US began during the mid-nineteenth century and to Australia after the Second World War. Since the early 1970s both countries have received waves of immigrants from all parts of the globe, with Australia experiencing especially marked flows from Asia. Both nations are now among the most multi-ethnic and multiracial societies in the world, though US racial divisions are more pronounced than Australia's.

Geographically, Australia and the US (below the 49th parallel) have landmasses nearly equal in size, but most of the US is arable and most of Australia is not. Especially important for immigration, Australia is an 
island continent whose territorial borders can be penetrated illegally only through lengthy and perilous sea voyages or readily detectable arrivals by air. Border protection in the US is much more difficult and expensive. There are northern and southern land borders that extend thousands of kilometres, and narrow and navigable seas that separate the southern US coastline from many populous and relatively impoverished Caribbean and Central American countries. Demographically, today's US population of 307 million is nearly 15 times Australia's 22 million. The US fertility rate of 2.0 per woman is close to the 2.1 replacement rate, but the Australian rate of 1.9 per woman is clearly below replacement, which makes population ageing and growth more pressing issues for Australia. Moreover, Australia's population is concentrated heavily in the capital cities of its six states - apart from Singapore, Australia is the world's most urbanized country - whereas US population concentrations are in scores of cities, at least 20 of which are equivalent to or larger than Australia's capital cities.

Australia is technically a constitutional monarchy (the British monarch is head of state) with a Westminster parliamentary system that has, however, important American features. These include a bicameral parliament with more or less coequal chambers, a written constitution and a High Court with powers of judicial review. The US is a presidential republic with a marked separation of executive, legislative and judicial authority. Both countries are federal systems in which states have important roles, but Australia's six states are generally less powerful than their 50 US counterparts (for example, 80 per cent of all tax revenues in Australia are collected and disbursed by the federal government). Australia has a highly professional and well-staffed public service; the US civil service is poorly paid, understaffed and weighed down by a thick layer of political appointees who often have little substantive knowledge of their portfolios. At least de facto, both countries have two-party systems-Democrats versus Republicans in the US, Labor versus a longstanding coalition of the Liberal and National parties in Australia (American spelling is used for the Australian Labor Party, the ALP). However, Australia's use of proportional representation for elections to its Senate encourages the presence of small parties and independents capable of blocking or altering legislation, while the need for super-majorities (60 of 100 votes) to pass major legislation in the US Senate enables senators to act independently of party affiliation and hold legislation hostage to concessions they individually seek. Finally, in a brief list of contrasts, voting in Australian elections is compulsory, so turnouts of eligible voters are regularly in the range of 94-95 per cent; voting in the US is voluntary, with turnout rates rarely approaching 60 per cent in presidential elections and much less than that in separate congressional, state and local elections. 


\section{DYNAMICS OF LABOUR MARKETS AND IMMIGRANT FLOWS}

The proportion of the world's population that migrates has been steady at around 3 per cent, or 190 million people, annually during recent decades. However, a recent Gallup survey found that 700 million adults, roughly 16 per cent of the world's adult population, wish to migrate to another country. If they all did so global migration would quadruple. Based on the Gallup survey sample, 165 million people designate the US as their most desired destination, and if they migrated to it the American population would increase by 50 per cent. If those designating Australia as their preferred destination actually migrated to it, the population would increase by 140 per cent (The Economist, 2009, p. 108). We have yet to see the full impact of harder economic times on migration flows, but recent reports suggest they are slowing. Fewer migrants are arriving in the major immigrant-receiving countries and the proportion of recently arrived migrants who stay put in those countries rather than return to home countries is increasing (Fix et al., 2009, p. 5).

The global reach of the economic crisis that began in 2008 sets it apart from earlier post-Second World War upheavals (Martin, 2009a, pp. 12-14) and it has had much to do with a slowing of migration to Australia and the US. Potential migrants have apparently been concluding that it is better to cling to whatever employment they have in countries where they are currently located than take a chance on finding better employment in the tightened Australian and US labour markets, especially the latter. During 2009, Australia's unemployment rate peaked at 5.8 per cent, but it fell back to 5.3 per cent by mid-2010. The official unemployment rate in the US exceeded 10 per cent during 2009 ( 8 million jobs lost), while the unofficial rate was closer to 20 per cent (15 million persons unemployed), and the flow of Mexican migrants to the US dropped by 13 per cent during the first quarter of 2009. Though stricter US border protection measures were one explanation, reduced labour market demand was almost certainly the key reason (Koser, 2009). At the same time, weakened labour markets in nearby sending countries - New Zealand's GDP decreased by 1.3 per cent and Mexico's GDP by 7.3 per cent during 2009-led migrants from those countries already located in Australia and the US to see little point in returning home. No indication of significant return migration from Australia and the US during 2008-09 was registered (Fix et al., 2009, p. 7). In sum, the risks and costs of migrating to and from both countries more closely offset the gains that might be achieved.

Reduced migrant remittances to home countries have been a further consequence of harder economic times. Between 2003 and 2008 remittances 
sent home by migrants in the US increased steadily and reached US $\$ 330$ billion in 2008 (Ratha, 2009). During 2009, however, total remittances sent from the US declined by about 10 per cent. Indeed, the Bank of Mexico recorded a decline of 16 per cent in remittances sent by Mexicans in the US during the first 11 months of 2009 (Buchanan, 2010). Because remittances from the US are second only to oil exports in Mexico's dollar earnings (the dollars acquired by Mexican drug cartels being unknown), the economic consequences for Mexico were severe, though by the end of 2009 the decline in remittances began to level off and Mexico's lost US dollar earnings were somewhat offset by a drastic fall in the peso's value against the dollar. In harder times, immigrants and migrants struggle to find or keep jobs and meet the costs of unavoidable moves and other dislocations. These difficulties pinch their ability to support families in their home countries.

\section{ALTERED POLICIES OF ADMISSION AND ENFORCEMENT}

To protect domestic labour markets and cushion workers against unemployment, as well as to ease public perceptions that migrants make hard economic times harder still, OECD countries have reduced immigration intakes, encouraged migrant departures and enforced border protection more strictly. In June 2010 the Australian government cut the official immigration intake by 21500 and reduced the number of migrants permitted to obtain a 457 temporary work visa by 12500 . This meant that the net overseas migration intake in the 2009-10 financial year was expected to fall to about 240000 , down 20 per cent from a peak of 306000 in the year to March 2009. As described by Peter Mares in Chapter 5, the federal government also took strong action against a spate of asylum seekers arriving illegally by boat and air. The US Department of Homeland Security (DHS) became more miserly in its grant of immigration visas - doubling visa application fees, for example - and in July 2010 President Obama sought to salve public anxieties about immigration by promising a 'comprehensive reform' of immigration policy in the not-distant future. Each country's open door to immigration during the preceding 15-20 years became less open.

In Australia during February 2010, following an extensive review of immigration policy by the Labor government, the minister for immigration announced what many regarded as the most fundamental reforms of Australia's skills-based migration programme in over 20 years. They centred on (1) altering the problematic link between permanent migration 
and the marketing of Australian education; and (2) instituting major changes in how Australia selects skilled migrants for permanent residence visas. The overall aim was to shift from a supply-driven to a demanddriven immigration programme. The federal government would now rely on employers in the private and public sectors to select and sponsor migrants they needed for jobs. This amounted to a major refinement of the emphasis on skilled migration that has characterized Australian policy since the late 1980s. The most important change was abolition of the Migration Occupations in Demand List (MODL), which had been created in 1999 and listed occupations deemed by the Department of Education, Employment and Workplace Relations to need additional workers. Aspiring migrants with qualifications and experience in the MODL-listed occupations scored extra points in the migration points test, and these extra points were often sufficient to obtain permanent residence visas. But as Peter Mares explained in a series of illuminating articles, occupations listed in the MODL frequently resulted from lobbying by business firms seeking to advance their specific interests. Consequently, the number of MODL occupations expanded from 30 in 2004 to more than 100 in 2009.

The MODL intersected, moreover, with other policy measures to distort the education export industry. Starting in 2001, international students graduating from Australian universities and colleges were able to apply for permanent residence. In 2005 alone, 17 new occupations, mainly in trades and engineering, were added to the MODL, thus encouraging many international students who hoped to reside permanently in Australia to enrol in vocational programmes leading to diplomas and degrees in such occupations. As Mares noted, this large expansion of the MODL produced an unanticipated boom in vocational courses, especially in cookery, hairdressing and accountancy, offered by for-profit colleges that emerged. As students graduated from these institutions in rapidly increasing numbers, their applications for permanent residence status created substantial delays in visa processing, with a backlog of 145000 applications in 2009 that included 12000 from newly certified cooks.

The Labor government's abolition of the MODL in 2010 weakened but did not completely sever the link between education and migration outcomes. Vocational colleges dependent financially on their provision of a route to permanent residence visas would no doubt dwindle in number, and others would be obliged to scale back enrolments. Transitional arrangements and a temporary 485 visa to protect students who had already invested heavily in vocational courses were allowed, but it will in future be much more difficult to have vocational education qualifications for permanent residence visas recognized. As Mares remarked: 
There is a great irony here. Australia has marketed itself to the world as a purveyor of high quality education and training. Yet it now has so little faith in the quality of the vocational sector of this industry that international graduates must go through a rigorous and expensive new assessment system-one that does not apply to domestic graduates in the same course.

Although the full implications of the 2010 reforms remain to be seen, it is likely that the proportion of employer-sponsored skilled migrants will rise and independent arrivals to Australia fall.

The size of Australia's annual immigration intake became more uncertain when Julia Gillard, who had been Deputy Prime Minister in the Labor government, replaced Kevin Rudd as Prime Minister in June 2010. One of Gillard's first steps was to distance herself from Rudd's stated desire for a 'big Australia'. She altered the recently created Population Minister's title to Minister for Sustainable Population and said she did not support 'hurtling down the track to a 36 or 40 million population' (The Australian, 2010a). Gillard proposed instead to put population sustainability front and centre in her government's policies. In response, the three major business associations - the Business Council of Australia, the Australian Industry Group and the Australian Chamber of Commerceproclaimed publicly that substantial population growth was nevertheless needed to support the economy and offset the existing population's aging. By contrast, compared with the early 1990s, when immigration as an issue of perceived importance politically in public opinion polls was ranked as 13th, in mid-2010 it had risen to fifth.

Another important focus of Australian political debate amid greater economic uncertainties was refugees and asylum seekers heading on boats towards the continent's north-west coast. Some 700000 people had come to Australia after 1945 as refugees or displaced persons at an average rate of about 11000 per year. During the late 1970s, under the Liberal-National Party coalition government headed by Malcolm Fraser, there was a bipartisan policy that welcomed some 150000 Indochinese refugees at an average rate of 25000 per year, many of them arriving by boat. In contrast, during the 12 months to June 2010 approximately 3500 boat people sought entry to Australia, most of them coming from Sri Lanka and Afghanistan, and a total of 12000 refugees and asylum seekers arrived between 2006 and mid-2010. Yet, in a climate of greater economic uncertainty, these comparatively paltry numbers provoked a political furore with which politicians had to deal. Prime Minister Gillard sought to assuage public fears that a tidal wave of asylum seekers was about to break on the country's shores by inviting Australians 'to feel free to say what they feel' about illegal asylum seekers without fear of being seen as intolerant or racist: 'I'd like to sweep away any sense that people should 
close down any debate . . through a sense of self-censorship or political correctness' (The Age, 2010).

A comparative Australian-US survey of attitudes in the two countries to unauthorized entry in 2010 produced a surprising result: the proportion of respondents expressing concern about unauthorized arrivals (75.5 per cent in Australia and 71.2 per cent in the US) was remarkably close (Iyengar and Jackman, 2010), despite the vast difference in numbers and relative proportions of annual unauthorized entries (4000 unauthorized arrivals in Australia in 2009 compared with approximately 500000 in the US the previous year).

Public anxieties about Australian immigration policies were as nothing, however, compared with the American uproar over immigration in a context of harder times. A comprehensive reform of immigration policy, which would have introduced a skills-based points system analogous to Australia's, failed to gain Senate passage in mid-2008 (see Freeman, 2009, pp. 65-69), and no further reform effort was attempted before or after the election of Barack Obama in November of that year. Measures to counteract the severe economic crisis and gain congressional passage of multi-faceted health care and financial regulatory reforms consumed the Obama administration's first two years in office, and it was widely believed that pro- and anti-immigration factional splits in both the Democratic and Republican parties guaranteed failure of any major immigration reform to win congressional passage. Rancorous discussion focused on what to do about the 11.5 million unauthorized migrants, more than half of them from Mexico, already in the country, and how to staunch the movement of still more unauthorized migrants across the land border with Mexico.

Recognizing that legislative proposals would be stymied, the Obama administration concentrated on actions lying within its executive purview. In 2009 DHS Secretary Janet Napolitano reminded the public that since 2007 the US Border Patrol had been increased to 20000 officers and an additional 600 miles of fence along the 2000-mile Mexican border had been erected, leaving some 400 miles unfenced. DHS stepped up detentions and deportations of unauthorized migrants arrested for misdemeanours and felonies, with upwards of 400000 migrants expected to be deported or allowed to leave on their own during 2010. The DHS shied away from the work-site raids conducted by the Bush administration to arrest unauthorized migrants and fine employers who hired them, and during fiscal year 2010 DHS raids resulted in arrests of just 765 migrants, compared with 5100 in the preceding fiscal year. Recourse was instead made to a computerized E-Verify system to audit employee documentation provided by 2875 companies suspected of hiring illegal workers, and fines were imposed on companies found to be doing so. Under a programme known 
as Secure Communities, the DHS also expanded its system of jails and prisons and used fingerprints to identify 240000 unauthorized migrants convicted of crimes, 30000 of whom had been deported by mid-2010.

These executive actions did little to quiet the immigration uproar, however. In April 2010 the Arizona state legislature passed a law, signed by the Republican governor, requiring local law enforcement officers to investigate the immigration status of individuals they apprehended when there is 'reasonable suspicion' of an illegal status. This provoked a storm of protests about the law encouraging racial profiling of Hispanics by police officers, it ignited many calls by Hispanic organizations and groups sympathizing with them to boycott Arizona goods and services, and as the day on which the law was to take effect-29 July 2010 - approached, groups vehemently opposed to it prepared to openly defy the law's enforcement. The federal Department of Justice sued Arizona's government for infringing federal control of immigration policy, and hours before the law was to take effect a federal district court judge prohibited enforcement of its most controversial components. Meanwhile, a growing number of US municipal and state governments adopted or prepared constitutionally dubious anti-immigrant laws, and the prospect of a chaotic jumble of federal, state and local efforts to control immigration and deal with unauthorized migrants loomed.

In May 2010 a CBS/New York Times poll indicated that 65 per cent of Americans considered immigration a 'very serious problem'. In that atmosphere President Obama felt compelled to order an additional 1200 National Guard troops to take up patrol positions along the Mexican border by August. In July he delivered a major speech in which he stated that unauthorized migrants living in the US must 'get right with the law before they can get in line and earn their citizenship'. They would have to register as unauthorized migrants, admit to having violated US law, pay fines for doing so, learn English and pass a general knowledge test. But though Obama promised a new effort at comprehensive immigration policy reform, he proposed no legislation. It seemed clear that comprehensive immigration reform would remain politically deadlocked well into the future.

\section{INTERNATIONAL STUDENTS}

Indicating the importance of educational exports for Australia's economy and educational institutions (AUS\$15 billion earned annually), 198417 temporary residence visas were granted to fee-paying international students during 2007-08, an increase of nearly 19 per cent over the preceding 
year (DIAC, 2009e). A large proportion of these students were enrolled in Australia's various tertiary education institutions. From 2001, as mentioned above, Australia allowed international students to apply onshore, with a AUS\$2000 application fee, for a permanent residence visa upon completing their studies. In 2008 some 40000 ex-students held temporary and bridging visas enabling them to remain in Australia indefinitely (Birrell and Perry, 2009). But when scandals surfaced about poorly regulated vocational colleges and schools abusing this policy for private gain, government efforts were made to eliminate the abuses, and requirements that international students must satisfy when seeking permanent residence status after completing their studies were toughened. During 2009, moreover, highly publicized physical assaults on students from India tarnished Australia's reputation as a welcoming location for international students. In early 2010 further attacks on Indian students, especially in Melbourne, became a sensitive issue between the governments of India and Australia, and the number of Indian students applying to study in Australia declined substantially.

The Labor government's changes to immigration policy in early 2010 provoked strong fears that a marked decline in international students would ensue, and that the disappearance of some teaching institutions and consequent dislocations of students enrolled in them would further undercut Australia's image as an attractive location for international students. Modelling by Access Economics suggested that in Victoria, the state most reliant on foreign students, there would be some 40000 fewer students in 2011 than in 2010. It was estimated that this would eliminate more than 10000 jobs and reduce Victoria's income from student fees and cost-ofliving expenditures by some AUS $\$ 1.17$ billion. During the nine months to March 2010, offshore grants to undertake tertiary-level studies in Australia declined by 20 per cent, and new enrolments in English-language programmes in Australia fell by 30 per cent. Recruiters of students in China forecast a decline of between 30 and 50 per cent in the number applying to study in Australia during 2011.

During the academic year 2007-08, 173121 international students were enrolled in US undergraduate, graduate and non-degree educational institutions (Institute of International Education, 2009), 40 per cent of them from China, India and South Korea. There was no evidence that harder economic times discouraged foreign students from undertaking studies in the US. Unlike in Australia, however, the US has had no well-instituted route through which international students can gain permanent residence visas. Students who complete their studies and who play vital roles in highpriority research teams and projects may apply for a change from their student status; other graduating students are eligible for a one-year work 
visa for purposes of practical training. But the great bulk of international students in the US are required to seek visa renewals annually and return to their country of origin upon completing their studies.

\section{MIGRANT DISPERSION AND INCLUSION}

Harder economic times have contradictory consequences for internal geographic mobility. On the one hand, people leave regions, cities and towns suffering economic downturns to look for greener pastures. Having lost their jobs or their homes to foreclosures, they are less anchored and living costs in localities not so badly affected become more affordable if jobs can be found there. On the other hand, people find it more difficult to relocate because they are less able to sell their homes, they perhaps owe more on mortgages than the homes are worth, they have lost savings with which a move could be financed, or they are simply too old for arduous relocations. Often lacking economic and social capital for moving, immigrants are likely to be stuck in places where they happened to settle before the economic downturn.

Little is yet known about how harder economic times have affected the internal geographic mobility of immigrants in Australia and the US (but see Robert Cushing's analysis of available US data in Chapter 8 of this volume). For a number of years prior to 2008 the Australian government offered immigrants inducements to locate outside major cities: bonus points were given to immigration applicants if they intended to settle in smaller communities; family and other immigrant sponsorships were tilted to promote geographic dispersion; smaller communities were provided with subventions aimed at bolstering their ability to attract immigrants. Still, most newly arrived immigrants continued to locate in the major Australian cities, and economic uncertainties have probably cemented their city locations. Florida in the US, a state with one of the fastest growing populations before 2008, experienced a net loss of 50000 people during 2008-09; California, battered by the economic crisis, lost 100000 people during those two years; and what had previously been strong population growth in Arizona and Nevada ceased altogether in 2009 (see Philip Martin's discussion of the dramatic Las Vegas 'boom and bust' in Chapter 2 of this volume). Texas and Oklahoma, whose energybased economies were less affected by the crisis, as well as the Washington, DC area, where federal government employment underpins the economy, registered continued population growth (The Economist, 2010, p. 22). But whether immigrants figured disproportionately in these contrasting mobility patterns was unclear. 


\section{SOCIAL COHESION}

Opinion surveys have long shown that in harder economic times public enthusiasm for immigration wanes and opposition to it waxes. Fears that newly arrived immigrants are taking jobs to which the native born believe themselves entitled increase community tensions and produce sporadic altercations that occasionally include violence. Protest demonstrations supporting or opposing existing immigration policies and intakes, as well as several unpleasant confrontations and a few assaults on individual immigrants, occurred in Australia and the US during 2008-09. In both countries a rising nativist thrust could be observed in fringe political movements, notably in the US 'tea party' movement. Although manifestations of anti-immigrant sentiment were limited, they signalled greater difficulties when managing the settlement of new immigrants.

In Australia, Professor Andrew Markus's second report for the Scanlon Foundation-Monash University-Australian Multicultural Foundation longitudinal survey (Markus, 2009) contained a surprise. Markus found that all the survey evidence he examined pointed to "the limited impact of the economic downturn and the lack of connection in the outlook of respondents between economic issues and immigration'. Markus concluded: 'Immigration issues (unlike the issue of people arriving by boat to seek asylum) have not become politicised; there was almost no partisan debate over immigration in the 12 months preceding the 2009 survey' (Markus, 2009, p. 17). Nonetheless, in the early part of 2010 two issuesviolence against several persons of Indian ethnicity and a further rise in the number of asylum seekers arriving illegally by boat (some 2000 on 50 boats during the first four months of 2010, compared with some 2700 on 60 boats during all of 2009) - kept immigration issues in newspaper headlines, as did debate over a government report forecasting population growth to 35 million by 2050. If the World Bank's fears of extended fragility in the international economy prove well founded (see above), Australia and the US will face many difficult immigration policy dilemmas during the next several years.

\section{POLICY DILEMMAS}

We began by observing that large-scale immigration is a political minefield, and this is all the more so in harder economic times. The disjunction between internal pressures to decrease inflows, and business and external migrant pressures to increase them, creates substantial conflict and forces significant policy adjustments. Adjustments include controversial efforts 
to beef up border protection and discourage unauthorized entrants. The reluctance of banks to make loans that enable companies to expand and new companies to start up limits the creation of many jobs immigrants would no doubt take. This fuels increased labour market competition between the recently arrived and the long settled, with heightened ethnic sensitivities, perhaps especially evident among second-generation offspring of immigrants (see the discussion by Susan Brown and Frank Bean of second- and third-generation Hispanic immigrants in Los Angeles in Chapter 6 of this volume).

Harder economic times have made the long-standing immigration policy dilemmas of Australia and the US more acute. The two countries have in common a need for skilled and unskilled immigrants in both the longer and shorter terms, and harder times have certainly not eliminated this need. In the longer term Australia's greatest challenges are likely to be finding ways to accommodate the infrastructural needs, demands on natural resources and impacts on the country's fragile environment that large inflows of immigrants entail. In the shorter term Australia faces at least three issues. The first concerns the public's deep sensitivities about the arrival of still-small numbers of asylum-seeking boat people. Opinion polls persistently show harsh public views about illegal asylum seekers. The second issue is how to ameliorate accusations that violence against individuals, particularly those of Indian ethnic origin, reflects a deepseated racism in Australian society. The third is the need for education services and job opportunities for new arrivals in outer suburbs of cities such as Melbourne and Sydney, to which immigrants are being pushed by inner-city housing costs, but in which transport and other facilities are poor. These issues would be difficult to handle irrespective of the economic climate and they influence how longer-term questions, such as the magnitude of immigration intake and investment necessary to accommodate this, are dealt with.

A further set of dilemmas faces the Australian federal government in the wake of its 2010 changes to the immigration programme; in particular, the shift from a supply-driven to a demand-driven programme. It is hard to fathom how a demand-driven programme can be reconciled with the government's desire to cap overall numbers of immigrants. It is equally hard to comprehend how increased employer-sponsored immigration, counterbalanced by decreased family-centred and independent immigration, can be managed without major complications and ructions.

The key dilemma that distinguishes the US immigration landscape from its Australian counterpart is the very large number of unauthorized migrants with whom the US must cope, but on whom much of the US economy also depends. The Department of Labor has estimated, for 
example, that half of all crop pickers in the US are unauthorized migrants. Meanwhile, the US is saddled with an inert immigration policy system that is at once convoluted and dated, making legal entry and exit cumbersome and slow. Even though flows of unauthorized migrants and numbers of illegal border crossings have recently diminished somewhat, more stringent border protection measures and granting amnesty to millions of unauthorized migrants already in the country are toxic issues.

Critics of existing immigration policies contend that the country has lost control of its borders; they see American workers as deprived of jobs and higher wages, and they portray health, education and other public services as overwhelmed by a 'flood' of unauthorized migrants. Critics contend also that the unauthorized migrants bring with them diseases, a proclivity for criminal behaviour and that there are terrorists among them. Defenders of the unauthorized migrants, and those favouring some form of amnesty, point out that they take jobs native-born Americans will not do, create much employment by consuming goods and services, and have a collective impact that is at worst neutral and probably on balance positive (Legomsky, 2009). However, US efforts to grapple with these conundrums have not resulted in significantly changed policies and laws, and they remain the greatest challenge for US immigration policy.

The chapters in this volume, written by prominent Australian and American immigration specialists, dissect these puzzles and policies and illuminate them with a wealth of research findings bearing on how immigration fares in harder times. 